\title{
Levels of protein fractions in blood serum of periparturient goats
}

\author{
Lenka Janků, Leoš Pavlata, L’ubica Mišurová, Jaroslav Filípek, Alena Pechová, \\ Rudolf Dvořák
}

\begin{abstract}
Ruminant and Swine Clinic, Faculty of Veterinary Medicine, University of Veterinary and Pharmaceutical Sciences Brno, Czech Republic
\end{abstract}

Received April 17, 2008

Accepted February 23, 2011

\begin{abstract}
The aim of the study was to compare contents of individual protein fractions determined by electrophoresis in blood serum of healthy periparturient goats. Eight clinically healthy white shorthaired goats were examined. Blood samples of these goats were taken from v. jugularis three weeks and two weeks before the anticipated parturition, on the parturition day, 7 days after the parturition, and 28 days after the parturition. Individual protein fractions, albumins, $\alpha 1-, \alpha 2-$, $\beta 1-, \beta 2$ - and $\gamma$-globulins were identified by electrophoretic analysis of blood serum. Percentage shares of individual protein fractions were converted from total protein values to $\mathrm{g} \cdot \mathrm{l}^{-1}$ values. The results indicated that individual serum protein fractions in periparturient goats showed significant dynamics of change. There were no significant differences between samples taken before the parturition and on the parturition day (except for the increase of $\beta 2$ from $2.5 \pm 0.3 \mathrm{~g} \cdot \mathrm{l}^{-1}$ observed 3 weeks before the parturition to $3.2 \pm 0.4 \mathrm{~g} \cdot \cdot^{-1}$ measured 2 weeks before the parturition, and the decrease of $\gamma \mathrm{G}$ levels from $9.5 \pm 2.6 \mathrm{~g} \cdot 1^{-1}$ observed three weeks before the parturition to $8.1 \pm 1.7 \mathrm{~g} \cdot \mathrm{l}^{-1}$ found on the parturition day), yet most indicators measured after the parturition were significantly higher $(p<0.05)$ than on the parturition day (values in $\mathrm{g} \cdot \mathrm{l}^{-1}$ observed on the parturition day versus values measured 28 days after the parturition: total protein $60.6 \pm 4.3$ vs. $71.3 \pm 2.4$, albumins $37.4 \pm 2.9$ vs. $42.7 \pm 1.0, \alpha 23.4 \pm 0.5$ vs. $4.1 \pm 0.8, \beta 15.6 \pm 0.5$ vs. $6.3 \pm 0.9$, $\gamma \mathrm{G} 8.1 \pm 1.7$ vs. $12.3 \pm 1.9)$. The results bring new knowledge on the values of individual fractions of serum proteins in healthy goats, which is necessary for diagnostic interpretation of pathological findings in animals and also for experimental studies.
\end{abstract}

Protein electrophoresis, albumin, $\alpha$-globulins, $\beta$-globulins, $\gamma$-globulins, acute phase proteins

Majority of plasmatic proteins is synthesized in hepatocytes, with albumin representing their largest quantitative part (Elmaouhoub et al. 2007). Except for albumin (protein), all plasmatic proteins are glycoproteins. Globulin fraction of serum proteins determined by electrophoresis involves $\alpha 1, \alpha 2, \beta 1, \beta 2$ and $\gamma$-globulins. Alpha1-globulins include $\alpha 1$-glycoprotein, $\alpha 1$-antitrypsin (AAT), $\alpha 1$-fetoprotein (AFP); $\alpha 2$-globulins include ceruloplasmin and haptoglobin. During electrophoresis, $\beta$-globulins are often separated to $\beta 1$ and $\beta 2$ globulin fractions that include transferrin, fibrinogen and complement components. Gamma-globulins include individual immunoglobulin classes.

Individual protein fractions, or blood serum proteins, have different functions and their identification is used also as a diagnostic tool. Many of these proteins are the so-called acute phase proteins. For instance, $\alpha 1$-acid glycoprotein (AGP) concentration increases during inflammation or infection, as well as concentrations of other acute phase proteins (CRP, serum amyloid A (SAA) protein, $\alpha 1$-antitrypsin, haptoglobin, ceruloplasmin and fibrinogen) based on increased synthesis of hepatocytes with subsequent release of these proteins in blood (Bauman and Gaudie 1994). Alfal-antitrypsin, member of the superfamily of proteinase inhibitors, has a crucial effect on inactivation of neutrophil elastase and other proteases, which maintains protease-antiprotease balance (Hashemi et al. 2007). Ceruloplasmin takes part in copper metabolism (binds 6 atoms) (Murray et al. 1998; Minatel and Carfagnini 2000) and its decreased plasmatic concentration is associated with copper deficiency (Kumar et al. 2004).

Address for correspondence:

doc. MVDr. Leoš Pavlata, Ph.D., Dip. ECBHM

Ruminant and Swine Clinic

Faculty of Veterinary Medicine

University of Veterinary and Pharmaceutical Sciences Brno

Palackého 1-3, 61242 Brno, Czech Republic

Phone: +420 541562407

Fax: +420 541562407

E-mail: pavlatal@vfu.cz

http://www.vfu.cz/acta-vet/actavet.htm 
Diagnostic utilization of the determination of certain protein fractions in ruminants has been reported e.g. in mastitis. Hirvonen et al. $(1996,1999)$ and Ohtsuka et al. (2001) have described increased haptoglobin concentration in cow serum. Kováč et al. (2007) recommend determining acute phase proteins (haptoglobin and SAA) in serum, and also in milk, as a useful tool for diagnostics of mastitis and possible indicator of milk quality.

Transferrin ( $\beta$-globulin) and albumin are multi-functional transport proteins that, among others, bind metal ions (Suznjevic 2001). Moreover, transferrin receptor facilitates endocytosis-mediated cellular absorption of iron (Feelders et al. 1999). Other studies on plasmatic proteins in $\beta$ fractions draw a link between degradation products of fibrinogen (plasmatic protein with high molecular weight) and microvascular leakage of e.g. albumin. Microvascular permeability induced in this way accompanies cardiovascular and cerebrovascular disorders (Tyagi et al. 2008). Certain proteins such as AFP have much higher diagnostic value in human patients where AFP belongs to the most important markers of hepatocellular carcinoma (Hu o et al. 2007). In ruminants, however, acute phase proteins (haptoglobin, fibrinogen, and ceruloplasmin) are clinically significant. They can be used mainly for diagnosis of inflammatory diseases.

Differences between male and female concentrations of certain acute phase proteins (AGP, haptoglobin) have been described e.g. by Clapperton et al. (2005, 2007). Cris tofól et al. (1998) determined individual fractions of serum proteins in dependence on the sex of sheep with a significant difference in albumin values. Tóthová et al. (2008) described that in the time around parturition there are significant changes in concentrations of acute phase proteins, as well as in the whole protein metabolism of dairy cows.

So far, the identification of concentrations of various serum proteins in goats has been described rarely (Fernandez et al. 2006). The aim of this study was to determine and evaluate the dynamics of serum protein concentrations in healthy goats in different stages of the reproductive and lactation cycle. These data represent the basis for correct interpretation of acquired values for diagnosis of diseases.

\section{Materials and Methods}

The experiment was performed on 8 breeding white shorthaired goats in their second lactation. The animals, healthy and showing no signs of any disease, were stabled in experimental pens of the Ruminant Clinic of the University of Veterinary and Pharmaceutical Sciences Brno. Animals were stabled on straw litter and fed twice a day a complementary diet consisting of barley $(30 \%)$, wheat $(20 \%)$, alfalfa meal $(18 \%)$, sunflower extracted unpeeled groats $(10 \%)$, wheat bran $(10 \%)$, maize $(5 \%)$, malt sprouts $(5 \%)$, dicalcium phosphate $(1.1 \%)$, sodium chloride $(0.7 \%)$, and calcium carbonate $(0.2 \%)$. Daily dose of this diet $(0.6 \mathrm{~kg}$ per animal) was fed in combination with hay, water and $\mathrm{NaCl}$ (lick) ad libitum.

Spontaneous parturitions were controlled by the veterinarian. All goats delivered vital kids. Puerperium was physiological in all animals. Colostrum and milk showed no sensory changes; none of the goats had mastitis.

Blood samples were taken by puncturing vena jugularis three and two weeks before parturition, on the parturition day, and 7 and 28 days after parturition. After the samples were precipitated, they were centrifuged at $1500 \mathrm{~g} 10 \mathrm{~min}$. The serum obtained in this way was kept frozen at $-20^{\circ} \mathrm{C}$ until it was examined.

Individual protein fractions were identified from serum by Hydragel Protein K20 (Sebia, France) electrophoretic set that is commonly used for separation of human serum proteins. Electrophoresis was done on alkaline agarose gel. Blood serum proteins were separated (in the direction from the positive pole) to albumins, $\alpha 1, \alpha 2, \beta 1, \beta 2$ and $\gamma$ globulins. Separated protein zones were stained with acid solution of amid black and evaluated by densitometry at $570 \mathrm{~nm}$ wavelength using DVSE (densitometer for electrophoresis gels) manufactured by Sebia. Percentage shares of individual protein fractions were converted from total protein (TP) values to $\mathrm{g} \cdot \mathrm{l}^{-1}$ values. Total protein was determined quantitatively by bio Vendor set. Total protein (biuret) was identified photometrically at $540 \mathrm{~nm}$ wavelength by biuret method using Cobas Mira device (Rosche, Switzerland).

Basic statistic characteristics of measured values and the evaluation of dynamics of value changes with time (using repeated measures ANOVA procedure and paired $t$-test, if the result ANOVA revealed $p \leq 0.01$ ) were processed using Microsoft Excel XP.

\section{Results}

The results of individual protein fractions in blood serum of healthy goats are presented in Table 1. They show that absolute values of individual indicators change significantly 
(with the exception of $\alpha 1$ globulin) with the stage of reproduction and lactation. There were no significant differences between samples taken before parturition and on the parturition day (except for the increase of $\beta 2$, and the decrease of $\gamma \mathrm{G}$ ), yet most indicators measured after parturition were significantly higher than on the parturition day.

Table 1. Concentrations of total protein and individual serum protein fractions $\left(\mathrm{g} \cdot \mathrm{l}^{-1}\right)$ identified by electrophoresis in periparturient goats (mean - $\mathrm{x}$; standard deviation - SD; minimum - min; maximum - max)

\begin{tabular}{|c|c|c|c|c|c|c|}
\hline & & $\begin{array}{c}3 \text { weeks } \\
\text { before } \\
\text { parturition }\end{array}$ & $\begin{array}{c}2 \text { weeks } \\
\text { before } \\
\text { parturition }\end{array}$ & $\begin{array}{c}\text { Day of } \\
\text { parturition }\end{array}$ & $\begin{array}{l}7 \text { days after } \\
\text { parturition }\end{array}$ & $\begin{array}{c}28 \text { days after } \\
\text { parturition }\end{array}$ \\
\hline \multirow{4}{*}{$\mathrm{TP}$} & $\mathrm{x}$ & $60.8^{\mathrm{aB}}$ & $60.9^{\mathrm{cD}}$ & $60.6^{\mathrm{eF}}$ & $65.1^{\text {ace }}$ & $71.3^{\mathrm{BDF}}$ \\
\hline & SD & 3.8 & 3.9 & 4.3 & 3.2 & 2.4 \\
\hline & $\min$ & 56.1 & 54.4 & 56.3 & 60.7 & 68.3 \\
\hline & $\max$ & 69.8 & 67.2 & 67.4 & 68.5 & 74.7 \\
\hline \multirow{4}{*}{ Alb } & $\mathrm{X}$ & $36.7^{\mathrm{A}}$ & $37.1^{\mathrm{B}}$ & $37.4^{\mathrm{C}}$ & $39.0^{\mathrm{D}}$ & $42.7^{\mathrm{ABCD}}$ \\
\hline & $\mathrm{SD}$ & 1.7 & 2.3 & 2.9 & 2.0 & 1.0 \\
\hline & $\min$ & 33.3 & 33.3 & 33.1 & 36.0 & 40.4 \\
\hline & $\max$ & 39.2 & 40.3 & 42.3 & 41.9 & 43.8 \\
\hline \multirow{4}{*}{$\alpha 1$} & $\mathrm{x}$ & 3.5 & 3.5 & 3.5 & 3.9 & 3.3 \\
\hline & SD & 0.5 & 0.4 & 0.6 & 0.7 & 0.6 \\
\hline & $\min$ & 2.4 & 2.6 & 3.1 & 2.3 & 2.3 \\
\hline & $\max$ & 4.0 & 4.0 & 4.1 & 4.9 & 4.2 \\
\hline \multirow{4}{*}{$\alpha 2$} & $\mathrm{x}$ & $3.1^{\mathrm{A}}$ & $3.2^{\mathrm{B}}$ & $3.4^{\mathrm{C}}$ & 3.4 & $4.1^{\mathrm{ABC}}$ \\
\hline & SD & 0.5 & 0.4 & 0.5 & 0.6 & 0.8 \\
\hline & $\min$ & 2.5 & 2.6 & 2.7 & 2.0 & 2.9 \\
\hline & $\max$ & 3.9 & 3.7 & 4.5 & 4.2 & 5.5 \\
\hline \multirow{4}{*}{$\beta 1$} & $\mathrm{x}$ & $5.5^{\mathrm{Ab}}$ & $5.4^{\mathrm{cD}}$ & $5.6^{\mathrm{Ef}}$ & $6.4^{\mathrm{AcE}}$ & $6.3^{\mathrm{bDf}}$ \\
\hline & SD & 0.3 & 0.3 & 0.5 & 0.8 & 0.9 \\
\hline & $\min$ & 5.0 & 4.9 & 5.0 & 5.2 & 4.9 \\
\hline & $\max$ & 6.1 & 5.7 & 6.6 & 7.6 & 7.7 \\
\hline \multirow{4}{*}{$\beta 2$} & $\mathrm{x}$ & 2.5 & $3.2^{\mathrm{ABc}}$ & $2.6^{\mathrm{A}}$ & $2.5^{\mathrm{B}}$ & $2.5^{\mathrm{c}}$ \\
\hline & SD & 0.3 & 0.4 & 0.2 & 0.2 & 0.6 \\
\hline & $\min$ & 1.9 & 2.6 & 2.3 & 2.3 & 2.0 \\
\hline & $\max$ & 2.7 & 3.6 & 2.9 & 2.9 & 4.1 \\
\hline \multirow{4}{*}{$\gamma \mathrm{G}$} & $\mathrm{x}$ & $9.5^{\mathrm{aE}}$ & $9.2^{\mathrm{bF}}$ & $8.1^{\mathrm{abCD}}$ & $9.9^{\mathrm{CG}}$ & $12.3^{\text {DEFG }}$ \\
\hline & SD & 2.6 & 2.3 & 1.7 & 1.6 & 1.9 \\
\hline & $\min$ & 6.1 & 6.0 & 5.2 & 7.3 & 10.0 \\
\hline & $\max$ & 15.6 & 14.6 & 11.3 & 12.6 & 16.1 \\
\hline
\end{tabular}

a:a-f:f on one line of the Table $=p<0.05$ (t-test), ${ }^{\text {A:A-G:G }}$ on one line of the Table $=p<0.01$ (t-test)

$\mathrm{TP}$ - total protein, Alb - albumin, $\alpha 1$ - $\alpha 1$-glubulins, $\alpha 2$ - $\alpha 2$-glubulins, $\beta 1-\beta 1$ - glubulins, $\beta 2$ - $\beta 2$ - glubulins, $\gamma \mathrm{G}-\gamma \mathrm{G}$-glubulins

\section{Discussion}

Mean of total protein concentration observed in this study ranged between $60.6 \mathrm{~g} \cdot \mathrm{l}^{-1}$ to $71.3 \mathrm{~g} \cdot \mathrm{l}^{-1}$. Before parturition and on the parturition day, TP was at the lower limit (or even slightly below) of the physiological range reported in other studies (Table 2). TP concentration started to increase gradually from day 7 after parturition with the highest mean concentration of $71.3 \mathrm{~g} \cdot \cdot^{-1}$ measured on day 28 after the parturition. It is likely that relatively low TP values obtained 3 weeks before parturition were affected by the fact that goats were already preparing for parturition, and by many immunological changes typical for this period. Similar changes of TP values in the goats' blood serum in puerperium were 
reported also by Krajničáková et al. (2003) who observed TP $65.48 \pm 3.15 \mathrm{~g} \cdot \mathrm{l}^{-1}$ on the first day after parturition, whereas TP values 40 days after parturition were $71.79 \pm 1.55$ $\mathrm{g} \cdot \mathrm{l}^{-1}$.

Albumin values significantly changed $(p<0.01)$ during the study as well (mean value gradually increased from $36.7 \mathrm{~g} \cdot \mathrm{l}^{-1}$ to $\left.42.7 \mathrm{~g} \cdot \mathrm{l}^{-1}\right)$, but largely remained within the reported physiological range (Table 2).

Table 2. Concentrations of total protein and albumins $\left(\mathrm{g} \cdot \mathrm{l}^{-1}\right)$ in blood serum of goats (our results compared with literature)

\begin{tabular}{lcc}
\hline & Total protein & Albumins \\
\hline Our results & $60.6-71.3$ & $36.7-42.7$ \\
Pugliese at al. (1982) & $59.4-96.6$ & $20.6-49.9$ \\
Lloyd (1982) & $60.0-78.5$ & $32.5-49.0$ \\
Jovanovič et al. (1989) & $52.3-99.4$ & $15.0-28.6$ \\
McDougal et al. (1991) & $62.0-89.0$ & $21.0-33.0$ \\
Kraft and Dürr (1999) & $65.0-75.0$ & $27.0-39.0$ \\
Fernandez et al. (2006) & $57.0 \pm 0.7$ & $24.0 \pm 0.4$ \\
\hline
\end{tabular}

Concentrations of $\gamma$ globulins in serum of experimental goats were considered the main indicators with significant changes. Significant decrease $(p<0.05)$ of $\gamma$ globulin concentrations on the parturition day corresponded with the transfer of $\gamma$ globulins to colostrum and subsequent increase $(p<0.01)$ of their concentrations, starting from day 7 after parturition, on a higher level than 3 weeks before parturition (from $9.5 \pm$ 2.6 to $\left.12.3 \pm 1.9 \mathrm{~g} \cdot \mathrm{l}^{-1}\right)$. Lower values measured before parturition should be associated mainly with the production of colostrum and other immunological changes typical for the periparturient period.

Although there are only few studies on the identification of protein fractions in goats by electrophoresis, our results can be compared e.g. with the results of Fernandez et al. (2006) who evaluated individual protein fractions identified by electrophoresis on agarose gel in goats naturally infected with gastrointestinal parasites. Fernandez et al. (2006) found the following values in goats: $57.0 \pm 0.7 \mathrm{~g} \cdot \mathrm{l}^{-1}$ of TP, $24.0 \pm 0.4 \mathrm{~g} \cdot \mathrm{l}^{-1}$ of albumin, $7.0 \pm 0.4 \mathrm{~g} \cdot \mathrm{l}^{-1}$ of $\alpha$ globulins, 7.0 $\pm 0.1 \mathrm{~g} \cdot \mathrm{l}^{-1}$ of $\beta 1$ globulins, $5.0 \pm 0.1$ of $\beta 2$ globulins and $15.0 \pm 0.4 \mathrm{~g} \cdot \mathrm{l}^{-1}$ of $\gamma$ globulins. It follows that generally lower total protein values are accompanied mainly by increased globulin fractions. The most significant difference between goats from our study and goats from the Fernandez study is in fractions $\beta 2$ and $\gamma$, as the sum of fractions $\alpha 1$ and $\alpha 2$ in our study was almost identical with the results of the overall $\alpha$ fraction observed by Fernandez et al. (2006). Higher values of infected goats were caused by parasitic infection with subsequent inflammatory reaction in the gastrointestinal tract, i.e. parasites were forced out via inflammatory reaction based on a major action of eosinophils, IgE and mast cells.

Comparison of our results with the results observed by Kraft and Dürr (1999) in cattle shows that the values of both animal species are similar. In cattle, 60-80 $\mathrm{g} \cdot \mathrm{l}^{-1}$ range of total protein was associated with the following ranges of protein fractions identified electrophoretically: albumin 32-42 $\mathrm{g} \cdot \mathrm{l}^{-1} ; \alpha 1$ globulin $1-3 \mathrm{~g} \cdot \mathrm{l}^{-1} ; \alpha 2$ globulin $3-6 \mathrm{~g} \cdot \mathrm{l}^{-1} ; \beta 1$ globulin 2-3 $\mathrm{g} \cdot \mathrm{l}^{-1} ; \beta 2$ globulin 3-6 $\mathrm{g} \cdot \mathrm{l}^{-1}$, and $\gamma$ globulin $6-8 \mathrm{~g} \cdot \mathrm{l}^{-1}$.

The results of our study bring new knowledge on the values of individual fractions of serum proteins in healthy goats, which is necessary not only when using the values for diagnostic interpretation of pathological findings in animals but also for their utilization in experimental studies. Moreover, these values reveal physiological changes that happen in periparturient goats and that should be taken into account when interpreting the results. Electrophoresis can be considered as an appropriate and effective method to be used for the determination of various serum protein fractions in blood of goats.

\section{Dynamika hladin sérových proteinů u koz v období kolem porodu}

Cílem práce bylo stanovení a porovnání hladin proteinových frakcí v krevním séru zdravých koz v období kolem porodu. Vyšetřováno bylo 8 klinicky zdravých bílých krátko- 
srstých koz, od kterých byly opakovaně odebírány vzorky krve a to 3. a 2. týden před očekávaným termínem porodu, $v$ den porodu, 7. a 28. den po porodu. Jednotlivé frakce bílkovin (albuminy, $\alpha 1$-, $\alpha 2-, \beta 1-, \beta 2$ - a $\gamma$-globuliny $(\gamma \mathrm{G})$ ) byly stanoveny ze séra elektroforeticky. Procentuální zastoupení jednotlivých frakcí bílkovin bylo přepočítáno $\mathrm{z}$ hodnoty celkové bílkoviny na hodnoty $\mathrm{v} g \cdot \mathrm{l}^{-1}$. Jednotlivé frakce sérových bílkovin u koz v období kolem porodu mají významnou dynamiku změn. Mezi odběry před porodem a $v$ den porodu nebyly většinou zjištěny průkazné rozdíly s výjimkou zvýšení $\beta 2 \mathrm{z} 2,5 \pm 0,3 \mathrm{~g} \cdot \mathrm{l}^{-1}$ 3 týdny před porodem na $3,2 \pm 0,4 \mathrm{~g} \cdot \mathrm{l}^{-1} 2$ týdny před porodem a opětovném poklesu na $2,6 \pm 0,2 \mathrm{~g} \cdot \mathrm{l}^{-1} \mathrm{v}$ den porodu a poklesu hladin $\gamma \mathrm{G} \mathrm{z} 9,5 \pm 2,6 \mathrm{~g} \cdot \mathrm{l}^{-1} 3$ týdny před porodem na $8,1 \pm 1,7 \mathrm{~g} \cdot 1^{-1} \mathrm{v}$ den porodu. Při odběrech po porodu byly hodnoty většiny parametrů průkazně vyšší $(p<0.05)$ než $\mathrm{v}$ den porodu (hodnoty $\mathrm{v} \mathrm{g} \cdot \mathrm{l}^{-1} \mathrm{v}$ den porodu versus 28 dní po porodu: celková bílkovina $60,6 \pm 4,3$ vs. $71,3 \pm 2,4$, Alb $37,4 \pm 2,9$ vs. $42,7 \pm 1,0, \alpha 23,4 \pm 0,5$ vs. 4,1 \pm $0,8, \beta 15,6 \pm 0,5$ vs. $6,3 \pm 0,9, \gamma \mathrm{G} 8,1 \pm 1,7$ vs. $12,3 \pm 1,9)$. Výsledky přinášejí nové poznatky o hodnotách jednotlivých frakcí sérových proteinů u zdravých koz, které jsou předpokladem pro jejich využití v interpretaci nálezů u zvířat v rámci diagnostiky chorob, ale i v rámci prováděných experimentálních studií.

\section{Acknowledgements}

Acknowledgments are due to laboratory and technical staff of the Ruminants Clinic of the Faculty of Veterinary Medicine of the University of Veterinary and Pharmaceutical Science Brno. This study was elaborated under the research project MSM6215712403.

\section{References}

Baumann H, Gaudie J 1994: The acute phase response. Imunol Today 15: 74-80

Clapperton M, Bishop SC, Cameron ND, Glass EJ 2005: Innate immune traits differ between Meishan and Large White pigs. Vet Immunol Immunop 104: 131-144

Clapperton M, Bishop SC, Pineiro M, Campbell FM, Glass EJ 2007: The association between plasma levels of acute phase proteins, haptoglobin, alpha-1 acid glycoprotein (AGP), Pig-MAP, transthyretin and serum amyloid A (SAA) in Large White and Meishan pigs. Vet Immunol Immunop 119: 303-309

Cristofol C, Navarro M, Franquelo C, Valladares JE, Arboix M 1998: Sex differences in the disposition of albendazole metabolites in sheep. Vet Parasitol 78: 223-231

Elmaouhoub A, Dudas J, Ramadori G 2007: Kinetics of albumin- and alpha-fetoprotein-production during rat liver development. Histochem Cell Biol 128: 431-443

Feelders RA, Kuiper-Kramer EPA, Van Eijk HG 1999: Structure, function and clinical significance of transferrin receptors. Clin Chem Lab Med 37: 1-10

Fernandez SY, Jesus EEV, Paule BJA, Uzeda RS, Almeida MAO, Guimaraes JE 2006: Proteinogram of alpine goat naturally infected by gastrointestinal parasites. Arq Bras Med Vet Zoo 58: 279-282

Hashemi M, Naderi M, Rashidi H, Ghavami S 2007: Impaired activity of serum alpha 1 antitrypsin in diabetes mellitus. Diabetes Res Clin Pr 75: 246-248

Hirvonen J, Pyörälä S, Jousimies-Somer H 1996: Acute phase response in heifers with experimentally induced mastitis. J Dairy Res 63: 351-360

Hirvonen J, Eklund K, Teppo AM, Huszenicza G, Kulscár M, Saloniemi H, Pyörälä S 1999: Acute phase response in dairy cows with experimentally induced Escherichia coli mastitis. Acta Vet Scand 40: 35-46

Huo TI, Hsia CY, Chu CJ, Hyuang YH, Lui WY, Wu JC, Lee PC, Chi CW, Lee SD 2007: The predictive ability of serum alpha fetoprotein for hepatocellular carcinoma is linked with the characteristics of the target population at surveillance. J Surg Oncol 95: 645-651

Jovanović J, Ivanov I, Damjanović Z, Jovović S, Jonić B, Marković S, Sirovica E 1989: Research important parameter in conversion metabolism profile (in Croatian). Vet Glasnik 43: 347-359

Kováč G, Popelková M, Tkáčiková l’, Burdová O, Ihnát O 2007: Interrelationship between somatic cell count and acute phase protein in serum and milk of dairy cows. Acta Vet Brno 76: 51-57

Kraft W, Dürr U 1999: Clinical laboratory diagnostic in veterinary medicine (in Czech). Hajko and Hajková, Bratislava, 365 p.

Krajničáková M, Kováč G, Kostecký M, Valocký I, Maraček I, Šutiaková I, Lenhard L 2003: Selected clinicobiochemical parameters in the puerperal period of goats. B Vet I Pulawy 47: 177-182

Kumar N, Gross JB, Ahlskog JE 2004: Copper deficiency myelopathy produces a clinical picture like subacute combined degeneration. Neurology 63: 33-39

Lloyd S 1982: Goat medicine and surgery. Brit Vet J 138: 70-85 
McDougal S, Lepherd E, Smith S 1991: Hematological and biochemical reference values for grazing Saanen goats. Aust Vet J 68: 370-372

Minatel L, Carfagnini JC 2000: Copper deficiency and immune response in ruminants. Nut Res 20: 1519 - 1529

Murray R, Granner D, Mayes P, Rodwell V 1998: Harper's Biochemistry (in Czech). H \& H, 706 p.

Ohtsuka H, Kudo K, Mori K, Nagai F, Hatsugaya A, Tajima M, Tamura K, Hoshi F, Koiwa M, Kawamura S 2001: Acute phase response in naturally occurring coliform mastitis. J Vet Med Sci 63: 675-678

Pugliese A, Chiofalo L, Domina F, Pennisi M, Magistri C, Catarsini O 1982: Metabolic profile by goats (in Italy). Ann Della Fac Di Med Vet Di Messina 19: 211-219

Suznjevic D, Erceg M, Vucelic D 2001: Indirect method for quantitative determination of bovine serum albumin and transferin by anodic stripping voltammetry with rotating glassy carbon electrode. Microchem J 69: 59-71

Tóthová CS, Nagy O, Seidel H, Konvičná J, Farkašová Z, Kováč G 2008: Acute phase proteins and variables of protein metabolism in dairy cows during the pre- and postpartal period. Acta Vet Brno 77: 51-57

Tyagi N, Roberts AM, Dean WL, Tyagi SC, Lominadze D 2008: Fibrinogen induces endothelial cell permeability. Mol Cell Biochem 307: 13-22 